\title{
Eduardo Blanquel
}

"Seguramente mi manía de profesor, mi enorme confianza en la gente joven, la idea de que uno se renueva cada día cuando habla con quienes son renuevo de cada dia, me hace ser eminentemente optimista y esperanzado."

E. Blanquel "Historia y humanismo"

La revista ESTUDIOS lamenta, junto a todos los que pudieron disfrutar de su amistad y su magisterio, la muerte del historiador Eduardo Blanquel.

En estas páginas publicamos dos brillantes ensayos suyos: "Presencia histórica del Estado mexicano" (No. 2) e "Historia y humanismo" (No. 3). Muchos estudiantes apreciaron sus lecciones de gran altura y son ya varias las generaciones de historiadores las que lo cuentan como maestro ejemplar.

Sus textos y sus clases, su legado, dejan en los historiadores jóvenes una inquietud: la del lúcido optimismo. 